\title{
Working Capital Management and Firms' Profitability: Evidence from Quoted Firms on the Nigerian Stock Exchange
}

\author{
F. O. Olaoye ${ }^{\circledR}$, J. A. Adekanbi, O. E. Oluwadare \\ Department of Accounting, Ekiti State University, Ekiti State, Nigeria \\ Email: oladipupo.olaoye@eksu.edu.ng
}

How to cite this paper: Olaoye, F.O., Adekanbi, J.A. and Oluwadare, O.E. (2019) Working Capital Management and Firms' Profitability: Evidence from Quoted Firms on the Nigerian Stock Exchange. Intelligent Information Management, 11, 43-60. https://doi.org/10.4236/iim.2019.113005

Received: March 23, 2019

Accepted: May 21, 2019

Published: May 24, 2019

Copyright $\odot 2019$ by author(s) and Scientific Research Publishing Inc. This work is licensed under the Creative Commons Attribution International License (CC BY 4.0).

http://creativecommons.org/licenses/by/4.0/

\begin{abstract}
Over the years, it appeared that firms failed to subject short-term investments to proper management thereby leading to either excessive or inadequate working capital which in turn affected their profitability. To empirically satisfy this, this paper examined working capital management and firms' profitability in Nigeria quoted firms on Nigerian Stock Exchange (NSE). A panel data methodology was used with different regression estimators to analyze this relationship based on a balanced panel of 10 listed firms during the period 2008-2017. It was discovered that cash collection period and cash payment period exerted a negative impact on return on assets, though the impact was only significant for cash payment period on the ground of $-0.064(p=0.000<0.05)$, as against the estimate for cash collection period that stood at $-0.032(\mathrm{p}=0.077>0.05)$. Also discovered was that both the current ratio and inventory period exerted a positive impact on return on assets, though the impact was only significant for current ratio on the ground of $8.172(\mathrm{p}=0.000<0.05)$, as against the estimate for inventory period that stood at $0.045(\mathrm{p}=0.438>0.05)$. The study concluded that working capital management affected firms' profitability in Nigeria. Therefore it was recommended that while the shorter collection was maintained, payment to creditors should not be elongated so as to enjoy cash discount (if any) and that firms should be proactive in the management of raw materials in order to avoid idle resources that might negatively impact their financial performance.
\end{abstract}

\section{Keywords}

Working Capital Management, Return on Assets, Cash Collection Period, Cash Payment Period, Current Ratio, Inventory Period 


\section{Introduction}

Universally, much attention has been accorded to long-term financial decisions including revolve capital decision, investment and dividends to mention just a few whereas, short-term financial decisions such as working capital are imperative to keep business as a going concern. Working capital is the difference between short-term assets and short-term liabilities, and the essence is to have the required cash needed for day to day operations. It, therefore, means that if the short-term goal is not achieved then, the long-term goals will be a mirage. Attesting to this, [1] observed that financial management of a firm was predicated on the operation of its short-term which then translates to long-term goals.

Working capital and the sequence it forms are managed by working capital management. It ensures that current liabilities don't exceed current assets so as to avoid liquidity problem and that the consciousness of liquidity should not override the ultimate goal of a business undertaking which is profit making. As opined by [2] [3] and [4], working capital management refers to the maintenance of a "balance" between current assets and current liabilities in order to guide against liquidity and profitability problems. Liquidity and profitability are two sides of the same coin because they work in opposite directions such that increasing liquidity of the firm will reduce profitability and vice versa.

Profitability evaluates the effectiveness and efficiency with which equipment, plant, and current assets are transformed into profits. It reveals how working capital has been effectively managed. Profitability, which could be determined through Return on Assets (ROA), Return on Equity (ROE), Net Profit Margin (NMP) and Profit after Tax (PAT), means a firm's ability to generate satisfactory return on invested capital through which shareholders are happy and prospective investors are motivated to invest [5]. To achieve the desired profit level and keep the business going, literature affirmed that the management of working capital components, particularly the cash conversion cycle, is indispensable in that firms' profitability might decrease if the costs of investment in working capital increase faster than the benefits of granting more trade credit to customers or holding more inventories [2] [6] [7].

It, therefore, means that the seemly poor performance of firms in Nigeria might not be unconnected to their failure to effectively and efficiently manage their working capital. As reported by [8], manufacturing firms are full of various vices that affect the management of short-term assets and short-term liabilities through which the expected profit is not made. Poor management of cash collection period, credit payment period, cash conversion and inventory policy have a greater effect on the operational activities, which in turn, affect the profitability level. While a longer collection period policy that leads to high sales but reduces liquidity for the smooth running of business activities is not profit-driven, a generous credit payment period is another flexible source of financing to improve business activities and sometimes can be expensive if a firm is offered a discount for the early payment. Thus, this clarifies why it is often argued that effective 
working capital management is very critical in realizing the primary goal of the firm, which is profit maximization.

It appears that firms in Nigeria have over the years failed to subject the nitty gritty of their short-term investments to proper management thereby leading to either excessive or inadequate working capital. While excessive working capital means idle resources yielding no profit, inadequate working capital is a detriment to operational activities in that it stagnates growth, reduces the efficiency of working capital and renders the firm unfit for attractive credit opportunities [3]. This demonstrates the necessity laid on a firm to balance working capital position in order to minimize risk, maintain adequate liquidity and raise the profit level at all times.

In relation to the researchers' knowledge, not much has been studied recently on the relationship between working capital management and profitability of firms in Nigeria. Worrisomely, the available studies have reported disaggregated findings thereby creating a platform for further studies. While studies like [3] [4] and [5] [8] and [9] reported a negative relationship between profitability and components of working capital used, studies like [6] [7] [10] and [11] reported a positive relationship. The vacuum created by these disaggregated findings constitutes the gap this present study intends to fill by using panel data methodology to examine working capital management and firms' profitability in Nigeria.

The timeliness of this study is found on the financial crunch that overwhelmed the whole economy thus affecting the operational activities of firms listed on the Nigeria Stock Exchange (NSE). The rest of the paper is divided into four sections. Section 2 covers the review of the literature; Section 3 centers on the research methodology; Section 4 presents and discusses the results of the analysis, while the last section; Section 5 , concludes the paper.

\section{Literature Review}

\subsection{Conceptual Issues}

\subsubsection{Working Capital Management}

Undoubtedly, working capital is indispensable to the operation of a business, particularly in the manufacturing sector where there is intermittent procurement of raw materials. It, therefore, means that successful operational activities of a firm revolve around its working capital. As described by [10] working capital is the total amount invested by a firm in its current assets for the day to day activities. In tandem, [12] described working capital as that part of a firm's capital set aside for meeting day to day requirements such as payment of wages, payment of creditors and procurement of raw material to mention but a few. The inference in these definitions is that working capital is the current or circulating capital needed by a firm to remain in business and meet its daily obligations.

Working capital as defined by [4] means current assets minus current liabilities, and this essence is to have a certain amount of money for day to day operations. Explaining further, [4] opined that for a firm to attain the expected profit 
level, its working capital must be in line with its operation. This informs that working capital should be moderately adequate; it must not be too much or too small. Having the right proportion of working capital in relation to business operations is one of the major factors that determine business success [6] [7].

Basically, there are three types of working capital namely permanent working capital, and temporary working capital. While permanent working capital is the minimum investments made by a firm to increase its current assets to carry a minimum level of operational activities; temporary working capital otherwise known to be fluctuating working capital means a changing working capital in relation to the production volume. This implies that fluctuating capital is the additional capital needed by a firm to cater for the changes in the production process and sales activities.

Working capital and the sequence it forms are managed by working capital management. The management of the current assets and a current liability of a firm is known to be working capital management. Asserting to this, [8] [13] and [3] jointly opined that working capital management is that part of a firm's finance that centered on maintaining adequate current assets to meet current liabilities so that the effectiveness and efficiency of the day to day operation is not grossly affected. Expanding this, [3] noted that both inadequate and excessive working capital is not palatable to a firm's success. While inadequate working capital engenders stagnation of growth, excessive working capital means idle funds with no gain or profit. Therefore, management must monitor and properly manage the periodic cash flow position through the cash flow statement analysis.

The preceding discussions on the nitty-gritty of working capital management underpin the need of manufacturing firms to have a proper working capital base to absorb shock predicted on the volatility of the economy, maintain adequate liquidity and increase the profit level. Only then a proper functioning of business operations will be ensured. Sound economic and statistical methods supported by informed judgment, should be used to forecast the quantum of working capital needed at the different level of operation [14].

\subsubsection{Concept of Profitability}

Universally, profit is the ultimate goal of organizations such that all the policies designed and activities performed are meant to realize this grand objective. However, this does not mean that companies have no other goals. Profitability evaluates the effectiveness and efficiency with which equipment, plant, and current assets are transformed into profit. [15] described profit as the excess of revenue generated over the cost in the production process within a definite period. It means the excess of revenue over net operating expenses.

In line with the submission of [16], profitability means a firm's ability to generate a satisfactory return on invested capital through which shareholders are happy and prospective investors are motivated to invest. Relatedly, shareholders 
are always interested in the ability of the company to use their limited assets efficiently and effectively to produce the desired profits. Return is judged by assessing earnings relative to the level and sources of financing in that a profit is not made when the operating expenses are not yet covered. To measure the profitability of companies, there are a variety of ratios used of which Return on Asset, Return on Equity and Net Interest Margin are the major ones [17].

Return on Equity is the ratio of Net Income after Taxes divided by Total Equity Capital [18]. It represents the rate of return earned on the funds invested in the organization by its shareholders. ROE reflects how effectively bank management is using shareholders' funds. ROA is also another major ratio that indicates the profitability of companies. It is a ratio of income to its total asset [18]. It measures the ability of the companies to generate income by utilizing company assets at their disposal. In other words, it shows how efficiently the resources of the company are used to generate income. NIM is a measure of the difference between the interest income generated by companies and the amount of interest paid out to their lenders (for example, deposits), relative to the amount of their (interest earning) assets. It is usually expressed as a percentage of what the financial institution earns on loans in a specific time period and other assets minus the interest paid on borrowed funds divided by the average amount of the assets on which it earned income in that time period [2].

\subsubsection{Components of Working Capital Management}

The processes of working capital management revolve crucial decisions on numerous facets, including the investment of available cash, managing accounts receivable, maintaining a certain level of inventories and accounts payable. The full description of these components and their expected relationship with profitability are given below:

\section{1) Cash Collection Period}

In the manufacturing sector, accounting receivable days are always used to proxy cash collection period. It is computed as average accounts receivable divided by sales, all multiplied by 365 days. The expectation is that this ratio should relate negatively with profitability in manufacturing firms. The expected negativity explains that increase in cash collection period will reduce the working capital for day to day operation and the effect will be felt on the profit level. Studies like [12] reported an inverse relationship between account receivables days and profitability.

\section{2) Credit Payment Period}

Account payable days is used to proxy credit payment day and it means how long it will take a firm to pay its creditors to keep the business relationship intact. It is computed as average accounts payable divided by cost of sales multiplied by 365 days. The expected relationship is that accounts payable days should have a positive relationship with the firm's profitability. This is because an increase in accounts payable days tends to afford firms more days to reinvest. Em- 
pirically, [19] reported a positive association between profitability and accounts payable days in their studies.

\section{3) Cash Conversion Cycle}

Cash conversion cycle is used to proxy the span of time in days it takes for a firm to change resource inputs into cash. The cycle is vital for firms in that it measures how quickly a firm can change its resources inputs into cash. The longer the cycle, the lengthier time capital is tied up and negatively affects the business operations and vice versa. It is computed as accounts receivable days plus inventory days less accounts payable days. In their study, [20] find a significantly negative relationship between profitability and CCC of 50 Nigerian listed non-financial firms.

\section{4) Current Ratio}

This is used to measure the liquidity of the firms. It is calculated as current assets divided by current liabilities. Firms are expected to increase profitability as their current ratio falls but not below one (1) as this prevents capital from being tied up in the business process [21]. In a study of some selected Saudi firms spread across 3 industries, [22] observes that a significantly negative relationship exists between profitability and a current ratio of the firms.

\section{5) Inventory Policy}

The number of days inventory is held (DINV) is used as a proxy for the inventory policy and is calculated as $(\mathrm{INV} \times 365) /$ cost of goods sold [12]. DINV reflects the average number of day stock is held by the firm. Longer storage days represent a greater investment in inventory for a particular level of operations. For a given level of inventory, the affectability of inventory control affects the flexibility of the firm, inefficient inventory control result to unbalance inventory and rigidity.

\subsubsection{Conceptual Framework of Working Capital Management}

As given in Figure 1, the objective of working capital management is to ensure optimal profit level through the minimization of the amount of capital tied up in the firm's current assets, liquidity management, controlling of the collection process and account receivables, and the management of the investment in inventory. Interestingly, a decision made on one of the working capital components has an impact on the other components and in order to maximize the performance of a business, the working capital management should be integrated into the short-term financial decision-making process.

\subsection{Theoretical Paradigm}

Theoretically, this study is underpinned by operating cycle theory and cash conversion cycle theory. Propounded in 1980 by [23], operating cycle theory exclusively revolves the working capital of a firm from the production process to collection of sales proceed. It gives income statement measures of a firm's operating activities, that is, about production, distribution, and collection [20]. For example, cash receivables are affected by the firm's policy of credit collection and the 


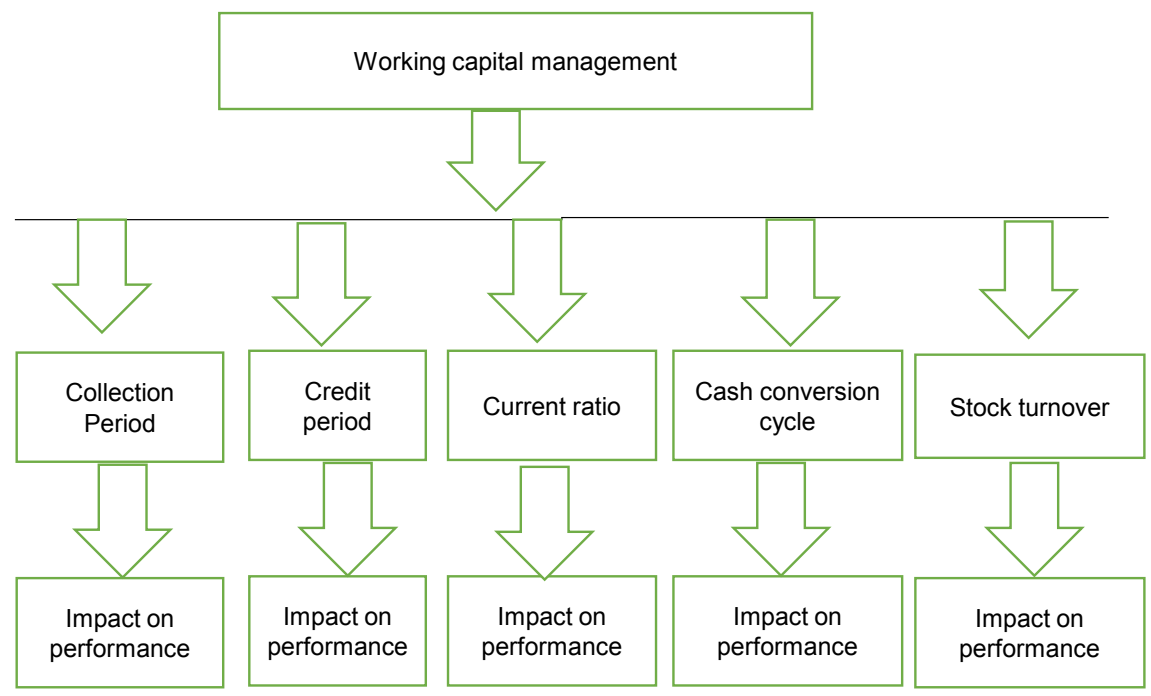

Figure 1. Conceptual framework of working capital management. Source: author's design.

frequency of changing or converting these receivables into cash is consequential to the processes that revolve working capital management. A generous credit policy through which the payment of the debtors is elongated might motivate customers to make purchase thereby increasing the profit level but at the same time, liquidity will be sacrificed. This theory has been well criticized on the ground that current liabilities are not important in the business operation of a firm thereby, distorting the general understanding that the essence of payables as a source of financing business obligations cannot be underestimated. Going by this, it is imperative to digest current liabilities in the picture for the enhancement of the analysis.

This theory integrates both sides of working capital, current assets, and current liability. It imbues current liabilities in the working capital so as to overcome the shortcoming of the operating cycle theory. Propounded in 1980 by [24], these scholars devised this method of working capital as part of an inclusive framework of analysis known as the working capital cycle. They claimed that the method is superior to other forms of working capital analysis that rely on ratio analysis or decomposition of working capital as claimed in the operating cycle theory. Therefore, CCC is the length of time between actual cash expenditures on productive resources and actual cash receipts from the sale of products or services [22]. The cash conversion cycle has been interpreted as a time interval between the cash outlays that arises during the production of output and the collection of accounts receivable [12].

CCC is likely to be negative as well as positive [25]. A positive result indicates the number of days a company must borrow or tie up capital while awaiting payments. A negative result indicates the number of days a company has received cash from sales before it must pay its suppliers [24]. However, the ultimate goal is having low CCC, if possible negative, because of the shorter the 
CCC, the more efficient the company in managing its cash flows and the better a firm's profitability [25]. This means that the firm uses less external financing and less time for cash tied up in current assets.

\subsection{Working Capital Management and Firms Profitability}

Universally, the essence of planning and management is to ensure that the stated objectives are achieved as and when due, and to equally maintain "balance" where necessary such that the smooth running of operational activities is not hindered. Explaining further, [26] noted that the management of working capital in an organization is to ensure effective and efficient synchronization of current assets and current liabilities with a singular aim of achieving operational, tactical and strategic goals. This underpins the plethora of literature on the significance of working capital management on the performance of organizations.

Over the years, disaggregated findings have been reported on the relationship between working capital management and profitability of organizations. Studies like [3] [4] [5] [8] [9] [16] and [27] reported a negative relationship between working capital management and profitability of organizations. Using 147 listed companies in Tehran Stock Exchange for the period of 2005-2009, [16] examined the relationship between working capital management and found out that there existed a negative relationship between working capital management and profitability. The scholars reported that an increase in working capital breeds decreases in the profit level.

Using 20 automobile industrials in India for the period of 1996-2009, [27] examined the relationship between working capital management and the firm's profitability. The result showed that there is a negative relationship between the length of the cash conversion cycle and firm profitability. Also, [28] studied the relationship between working capital management and corporate performance of 204 manufacturing firms listed on Karachi Stock Exchange in Pakistan for the period 1998 to 2007 using 2040 firms-year observations. They found that Operating Profitability is negatively associated with measures of working capital management (Average Collection Period, inventory turnover in days, Average Payment Period, Cash Conversion Cycle and Net Trade Cycle).

The negative relationship reported might be due to their choice of predictor and outcome variables, a method of analysis and the nitty gritty of the sampled size. This informs the crux of this present study to unravel the best way to manage working capital and ensure that the profitability is not affected negatively. Another study conducted by [8] on the impact of working capital management on profitability potential companies listed in Tehran Stock Exchange during the period 2001-2008 showed that there is a significant negative relationship between the cash conversion cycle with return on assets. Increasing liquidity of the firm will reduce the profitability of the firm and vice versa. So, the dilemma in working capital management is to achieve the desired tradeoff between liquidity and profitability. 
Supporting this, the study conducted on the impact of working capital management on the profitability of firms by [29] in Pakistan equally revealed a negative relationship. The scholar used 94 Pakistani firms listed at Islamabad Stock Exchange (ISE) for five years, spanning from 1999-2004. Corroboratively, using quoted food and beverages manufacturing firms in Nigeria, [4] undertook a study to examine working capital management and profitability of firms. The analysis that was carried out via multiple regression revealed that Account collection Period had significant negative relationships with profitability and Inventory Conversion Period and Account Payment Period had an insignificant negative relationship with profitability. The scholar lamented the significance of working capital management for the survival of the organization, particularly in Nigeria the volatility of the economy is worrisome.

Regrettably, in Nigeria, [30] submitted that many firms in the manufacturing sector had crashed consequent on the inadequacy of working capital. This might not be unconnected to the failure of these firms to be fully conscious of the dynamism of the Nigeria economy where things are unpredictable. Explaining further, [30] noted submitted that many factories had been either temporarily or completely shut down because they could not meet their financial obligations as at when due because they were not liquid. The corollary of the findings indicated that working capital management is indispensable to the growth and survival of organizations, especially the manufacturing firms.

Interestingly, the relationship between working capital management and profitability is not totally negative, as some studies reported a positive relationship. Using multiple regressions to test the formulated hypotheses on their study titled working capital management and firms' performance on manufacturing companies listed on the Nigerian Stock Exchange (NSE) for period 2008-2012, it was concluded that it also revealed that the profit is significantly influenced by the number of days inventory held (INVP). Although the scholar also reported a negative relationship between cash conversion cycle and profitability, [31] also studied the relationship between working capital management and corporate performance of 204 manufacturing firms listed on Karachi Stock Exchange in Pakistan for the period 1998 to 2007 using 2040 firms-year observations. They found that Operating Profitability is negatively associated with measures of working capital management (Average Collection Period, inventory turnover in days, Average Payment Period, Cash Conversion Cycle and Net Trade Cycle).

In a related study but with a long number of years, the study conducted by [7] on the impact of working capital management on the profitability of manufacturing firms in Nigeria, it was concluded through the analysis carried out via regression that working capital management had a significant association with the profit level of Guinness Cadbury and Unilever. The inference of these positive outcomes is that when a firm maintains the best mix of the components of working capital, its influence would put smiles on the faces of the shareholders. Also, [28] studied the effect of working capital on the profitability of firms in 
Nigeria for the period 1999 to 2007 using data collected from annual reports of 66 listed firms on the Nigerian Stock Exchange. The results of her study show that the cash conversion cycle, account receivables and inventory period are positively related to profitability while account payable is negatively related to profitability.

Similarly, using ordinary least square method to analyze the influence of sales, operating leverage, financial leverage and combined leverage on the performance of manufacturing firms in Nigeria between 1979 and 2004, [6] concluded that operating leverage, sales, financial leverage, and combined leverage have a significant influence on firms' earnings. In the same vein, [2], reported that accounts payable has a positive relationship with profitability while average collection period, inventory turnover and cash conversion cycle have a negative relationship with profitability.

Examining the relationship between working capital management and the profitability of firms listed on Athens Stock Exchange for the period of 2001-2004 by [10], a significant relationship between CCC and its components and operating profit was reported. In tandem, Hamid and Wager in Pakistan found a positive relationship between profitability and working capital management and concluded that efficient working capital management plays an imperative role in the enhancement of profitability of the firms. This implies that managers could enhance the profit level by keeping each component of working capital on an optimum level.

Literature affirms disaggregated findings on the relationship between working capital management and the profitability of firms in a different sector of the economy and in different countries across the world. In the same vein, the dearth of recent studies necessities this present study if different findings could be made. Also, the study is equally timely in that the country is not totally healed by the financial crises that engraved virtually every sector.

\section{Methodology}

The ex-post facto research design was employed in that it is generally considered suitable for after the fact researches. The data utilized was gathered from the published financial statements of the chosen manufacturing firms listed on the Nigeria Stock Exchange (NSE) from 2008-2018. According to the report on the official site of Nigeria Stock Exchange (NSE), there are 11 sectors, out of which one (1) firm was randomly selected from all the sector except financial sector which was excluded in the study, resulting to a total sample size of ten (10) firms. The firms randomly chosen were Presco Plc, A. G. Levent, Julius Berger, Guinness, May \& Baker, NCR (Nigeria) Plc., Beta Glass Co Plc., B.O.C. Gases, Total Nigeria Plc, and Red Star Express. Data were collected on a single performance variable of Return on Assets (ROA) and components of working capital such as collection period, credit period, inventory period and current ratio. The study comparatively adopts fixed effect model and random effect model of panel 
data analysis. The fixed effect follows the form present below:

$$
Y_{i t}=a_{0}+\beta_{1} X_{i t}+\delta i+\mu_{i t}
$$

$\delta i$ is a time-varying intercept that captures all the variables that affect $Y_{i t}$ that vary over time but are constant cross-sectionally. In substituting the variables under consideration into the fixed effect model, it will appear thus:

$$
R O A_{i t}=a_{0}+\beta_{1} C C P_{i t}+\beta_{2} C R A_{i t}+\beta_{3} I V P_{i t}+\beta_{4} C P P_{i t}+\delta i+\mu_{i t}
$$

where:

ROA is Return on Assets, CCP is Cash Collection Period, CPP is Cash payment Period and CRA is Current Ratio and INP is Inventory Policy. The random effect model follows the forms presented below:

$$
Y_{i t}=a_{0}+\beta_{1} X_{i t}+W_{i t}, W_{i t}=£_{i t}+\mu_{i t}
$$

where $£_{i t}$ measures the random deviation from the global intercept a, subscript "it" represents the combination of time and individuality. $U_{i t}$ means error term. In substituting the variables under consideration into the fixed effect model, it will appear thus:

$$
R O A_{i t}=a_{0}+\beta_{1} C C P_{i t}+\beta_{2} C R A_{i t}+\beta_{3} I V P_{i t}+\beta_{4} C P P_{i t}+\left(\delta i+\mu_{i t}\right)
$$

The selection of the best-suited model from the two is done following the Hausman test as presented by [26]. This test represents a distance measure between Random Effect Model and Fixed Effect Model with an $\mathrm{H}_{0}$ that the Random Effects are better, consistent and efficient and an $\mathrm{H}_{1}$ that Fixed Effects are better, consistent and efficient. Therefore, rejecting the alternative hypothesis means Random effects are upheld as against the Fixed Effect. Table 1 shows the proxy variables, definitions, and predicted relationship.

\section{Results and Discussion}

\subsection{Results}

This chapter presents the analysis made of the data gathered and tests of hypotheses. It presents the results of the descriptive statistics which provide summary statistics for the variables of the study. Thereafter, it presents the relationship between the predictor variables and outcome variable using Pearson correlation matrix and regression analytical tools.

Table 1. Proxy variables, definitions, and predicted relationship.

\begin{tabular}{clc}
\hline Proxy Variables Definitions & Predicted Sign \\
\hline CCP & Accounts receivables divided by sales and multiplied by 365 days & $+/-$ \\
CPP & $\begin{array}{l}\text { Accounts payables divided by cost of goods sold and multiplied } \\
\text { by } 365 \text { days }\end{array}$ & $+/-$ \\
CRA & current assets divided by current liabilities & $+/-$ \\
IVP & $\begin{array}{l}\text { Inventory divided by cost of goods sold and multiplied by } 365 \\
\text { days }\end{array}$
\end{tabular}


The discovery Table 2 indicates that the Return on Assets (ROA) of the ten 10 sampled companies for the period of 2008-2017 have an average value of $10.48 \%$ ranged from a negative return of $21.44 \%$ to a maximum of $45.73 \%$. The inference is that for every one naira invested, the industry had made a loss of N21.44 and had made a maximum gain of N45.73. equally, the average value of ROA reported to be 10.48 indicates that every firm in the industry could make an average of $10.48 \%$ on the net investment with a higher degree of risk as the returns varied at both sides of the scale by a large margin of $9.821 \%$. The credit period the companies granted their clients averaged 56 days while they paid their creditors in 40 days on the average. Whereas their debtors could remain outstanding for a maximum of 280 days, the firms were not paying their bills earlier than a single day. It took an average of 17 days to convert inventories into sales. While at a particular time, some firms in the industry were able to shorten this range to only 1 day, others could not turn inventories into sales till after 138 days. The average value of the current ratio given to be $1.28 \%$ indicates that all the sampled firms in the industry have the capacity to increase profitability.

The outcome in Table 3 revealed that there is a negative relationship between Return on Assets (ROA), Cash Collection Period (CCP) and Cash Payment Period (CPP) with a correlation coefficient of 0.13964 and 0.36252 . This implies that as CCP and CPP reduce by $1.4 \%$ and $3.6 \%$ respectively, ROA will increase by the same percent but not significantly. In the same vein, the outcome reveals that there is a positive relationship between Return on Assets (ROA), Current Ratio (CRA) and Inventory Period (IVP) with a correlation coefficient of 0.4185 for ROA and CRA and 0.2308 for ROA and IVP. This implies that ROA moves in the same direction as CRA and IVP. The implication is that as CRA and IVP increase, ROA will increase by $4.2 \%$ and $2.3 \%$ for CRA and IVP respectively. Likewise, the correlations within the explanatory variables prove lack of multicollinearity as the highest correlation coefficient is that of CRA and IVP with a positive value of 0.3383 .

Table 4 presented the outcome of the pooled OLS result, Fixed effect estimation, and random effect estimation. From the pooled OLS estimation column, the outcome revealed that both Cash Collection Period (CCP) and Cash Payment Period (CPP) exert a negative significant impact on Return on Assets (ROA) to the tune of $-0.046(\mathrm{p}=0.019<0.05)$ for CCP and -0.044 ( $\mathrm{p}=0.003<$ 0.05) for CPP. Consequently, there exists a positive influence of both Current Ratio (CRA) and Inventory Period (IVP), though the influence is only significant for CRA to the tune of $7.147(\mathrm{p}=0.000<0.05)$ and not for IVP with 0.033 and 0.282 for the coefficient estimate and p-value respectively. R-square reported to be 0.340 indicates that the predictor variables considered accounted for about $34 \%$ change in the outcome variable, while the remaining of the change covered by $66 \%$ was as a result of other variables not addressed by this study. Likewise, the Prob (F-stat) of 0.0000 which was less than 0.05 proved the model to be fit. 
Table 2. Descriptive statistics.

\begin{tabular}{cccccc}
\hline & ROA & CCP & CRA & IVP & CPP \\
\hline Mean & 10.47960 & 56.01828 & 1.275657 & 16.67586 & 40.64646 \\
Median & 9.010000 & 53.23000 & 1.120000 & 6.810000 & 22.00000 \\
Maximum & 45.73000 & 280.4800 & 3.240000 & 137.5000 & 395.0000 \\
Minimum & -21.44 & 0.000000 & 0.000000 & 0.000000 & 0.000000 \\
Std. Dev. & 9.821586 & 47.51895 & 0.609699 & 29.72000 & 61.96367 \\
Skewness & 0.673755 & 2.339953 & 0.826958 & 2.887342 & 3.619344 \\
Kurtosis & 5.770819 & 11.02555 & 3.784519 & 9.942634 & 17.26857 \\
\hline
\end{tabular}

Where: ROA is Return on Assets, CCP is Cash Collection Period, CPP is Cash Payment Period and CRA is Current Ratio and IVP is Inventory Policy.

Table 3. Correlation matrix.

\begin{tabular}{cccccc}
\hline Variables & ROA & CCP & CRA & IVP & CPP \\
\hline ROA & 1.000000 & & & & \\
CCP & -0.13964 & 1.000000 & & & \\
CRA & 0.418498 & 0.288767 & 1.000000 & & \\
IVP & 0.230808 & 0.224887 & 0.304355 & 1.000000 & \\
CPP & -0.36252 & 0.244601 & -0.03231 & -0.16973 & 1.000000 \\
\hline
\end{tabular}

Where: ROA is Return on Assets, CCP is Cash Collection Period, CPP is Cash Payment Period and CRA is Current Ratio and IVP is Inventory Policy.

Table 4. Regression result of working capital management and firms' profitability.

\begin{tabular}{|c|c|c|c|c|c|c|c|c|c|}
\hline \multirow[b]{2}{*}{ Variable } & \multicolumn{3}{|c|}{ POOLED EFFECT } & \multicolumn{3}{|c|}{ FIXED EFFECT } & \multicolumn{3}{|c|}{ RANDOM EFFECT } \\
\hline & Coeff & Std. Err & Prob & Coeff & Std. Err & Prob & Coeff & Std. Err & Prob \\
\hline $\mathrm{C}$ & 5.176275 & 2.0282 & 0.0123 & 3.421653 & 1.95921 & 0.0843 & 3.907665 & 2.4583 & 0.1153 \\
\hline CCP & -0.04592 & 0.01917 & 0.0186 & -0.02916 & 0.01854 & 0.1195 & -0.03229 & 0.01807 & 0.0771 \\
\hline CRA & 7.146863 & 1.46088 & 0.0000 & 8.349824 & 1.40996 & 0.0000 & 8.17202 & 1.3674 & 0.0000 \\
\hline IVP & 0.032623 & 0.03013 & 0.2817 & 0.054273 & 0.06006 & 0.3687 & 0.034961 & 0.04489 & 0.4381 \\
\hline CPP & -0.04392 & 0.01412 & 0.0025 & -0.07049 & 0.0143 & 0.0000 & -0.06444 & 0.01379 & 0.0000 \\
\hline R-Squared & & 0.339926 & & & 0.581844 & & & 0.4227 & \\
\hline $\begin{array}{c}\text { Adj. } \\
\text { R-Squared }\end{array}$ & & 0.311838 & & & 0.517891 & & & 0.398135 & \\
\hline F-Stat & & 12.10209 & & & 9.097957 & & & 17.20677 & \\
\hline Prob (F-Stat) & & 0.000000 & & & 0.000000 & & & 0.000000 & \\
\hline
\end{tabular}

Similarly, from the fixed-effect model result of Table 4, it could be gathered that $\mathrm{R}$-square value 0.582 , reflect that about $58.2 \%$ of the systematic variation in ROA can be explained jointly by the explanatory variables CCP, CRA, IVP, and CPP. Likewise, the Prob (F-stat) of 0.0000 which was less than 0.05 proved the 
model to be fit. On the direction and significance of the predictor variables, the outcome revealed that both Cash Collection Period (CCP) and Cash Payment Period (CPP) exert a negative impact on Return on Assets (ROA) with coefficients estimates of -0.029 and -0.070 respectively. Although, the negative impact of CCP is not significant like that of CPP that is significant with their respective $p$-values of 0.120 and 0.000 . In the same vein, there exists a positive influence of both Current Ratio (CRA) and Inventory Period (IVP), though the influence is only significant for CRA to the tune of $8.350(\mathrm{p}=0.000<0.05)$ and not for IVP with 0.054 and 0.369 for a coefficient estimate and p-value respectively.

Random effect estimation result presented in Table 4 revealed that when heterogeneity effect across firms and over time is incorporated into the model via the error term, both CCP and CPP exert negative impact on ROA, though the impact is only significant for CPP, on the ground of $-0.064(\mathrm{p}=0.000<0.05)$, as against estimate for CCP that stood at $-0.032(\mathrm{p}=0.077>0.05)$. Similarly, both CRA and IVP exert a positive impact on ROA, though the impact is only significant for CRA, on the ground of $8.172(p=0.000<0.05)$, as against estimate for IVP that stood at $0.045(\mathrm{p}=0.438>0.05)$. Reported R-square stood at 0.423 which implies that about $42.3 \%$ of the systematic variation in ROA can be explained jointly by CCP, CRA, IVP, and CPP of the sampled firms.

Table 5 reported chi-square statistics of 3.8721 along with its probability value of 0.4236 indicating that there is not enough evidence to reject the null hypothesis that differences in coefficients of fixed effect estimation and random effect estimation are not significant. Therefore, the most consistent and efficient estimation is given by the random effect estimation which revealed both CCP and CPP exert negative impact on ROA, though the impact is only significant for CPP, on the ground of $-0.064(\mathrm{p}=0.000<0.05)$, as against estimate for CCP that stood at $-0.032(\mathrm{p}=0.077>0.05)$. Similarly, both CRA and IVP exert a positive impact on ROA, though the impact is only significant for CRA, on the ground of $8.172(\mathrm{p}=0.000<0.05)$, as against estimate for IVP that stood at $0.045(\mathrm{p}=$ $0.438>0.05)$.

\subsection{Discussion of Findings}

The result of the analysis carried out revealed that both cash collection period (CCP) and cash payment period (CPP) exerted a negative impact on Return on Assets (ROA), though the impact was only significant for CPP as against the estimate for CCP that is not significant. The implication of these discoveries is that increase in the days of the collection period would breed a decrease in the profitability of firms in the industry, though not significantly. The implication is that more profitable firms have a shorter accounts receivable period. In the same vein, an increase in the days of the payment period would engender a decrease in the profitability of firms significantly. The implication is that firms should not encourage a longer payment period as this will reduce their profit level. This 
Table 5. Hausman test.

\begin{tabular}{ccc}
\hline Null hypothesis & Chi-square stat & Probability \\
\hline The difference in coefficient not systematic & 3.8721 & 0.4236 \\
\hline
\end{tabular}

Source: Authors' Computation, 2019.

gave credence to the findings of [28]. They reported that operating profitability is negatively associated with measures of working capital management such as Average Collection Period and Average Payment Period. However, these outcomes negate the conclusion of [32] and Gul et al. (2013) on the ground that account receivable relates positively with profitability.

Another discovery made was that both the current ratio and inventory period exert a positive impact on return on assets, though the impact is only significant for the current ratio. The corollary of this outcome in relation to inventory period is that a day increase in inventory period would bring about an increase in the profit level insignificantly. This is against the expected result that the increase in inventory period would reduce the profitability of firms in the industry. The inference is that this might constitute the reason why some firms are not doing excellently well in the industry in that longer days of inventory would tie down resources which will in turn negatively reflect in the profit level. This outcome negated the discovery of [4] [20] and [12], that inventory period had an insignificant negative relationship with profitability. However, this outcome was in tandem with the findings of [32]. Also, [22] submitted that a significantly negative relationship exists between profitability and the current ratio of firms as against the outcome made in this study.

\section{Conclusion and Recommendations}

It appeared that the management of firms in Nigeria has over the years failed to subject short-term investments to proper management thereby leading to either excessive or inadequate working capital which in turn affect their profitability. This is the crux of this study and it was concluded that cash collection period exerted a negative insignificant influence on return on assets of the sampled manufacturing firm for the period covered, 2008-2010; cash payment period exerted a negative significant influence on return on assets of the sampled manufacturing firm for the period covered, 2008-2010; current ratio exerted a positive significant influence on return on assets of the sampled manufacturing firm for the period covered, 2008-2010 and that inventory period exerted a positive significant influence on return on assets of the sampled manufacturing firm for the period covered, 2008-2010. Based on these discoveries, it was therefore recommended that firms should maintain a shorter cash collection period as this was expected to increase the shareholders' value; elongated credit payment period should not be appreciated by firms so as to enjoy cash discount that might improve the profit level; store management should be accorded a great importance 
as this was expected to solve inventory-related problems, and that firms should be proactive in the management of raw materials in order to avoid idle resources that might negatively impact their financial performance. Finally, the researcher recommends conducting further studies and researches on working capital management and firms' profitability in the banking sector.

\section{Conflicts of Interest}

The authors declare no conflicts of interest regarding the publication of this paper.

\section{References}

[1] Jason, K. (2017) The Effect of Working Capital Management on Profitability: A Case of Listed Manufacturing Firms in South Africa. Investment Management and Financial Innovations, 14, 336-346. https://doi.org/10.21511/imfi.14(2-2).2017.05

[2] Gill, A., Biger, N. and Neil, M. (2010) The Relationship Between Working Capital Management and Profitability: Evidence from The United States. Business and Economics Journal, 2010, BEJ-10.

http://astonjournals.com/manuscripts/Vol2010/BEJ-10_Vol2010.pdf

[3] Uremadu, J.A., Egbide, B. and Enyi, P.E. (2012) Working Capital management, Liquidity and Corporate Profitability among Quoted Firms in Nigeria: Evidence from the Productive Sector. International Journal of Academic Research in Accounting, Finance and Management Sciences, 2, 80-97.

[4] Osundina, J.A. (2014). Working Capital Management and Profitability: Evidence From Quoted Food and Beverages Manufacturing Firms in Nigeria Research. Journal of Finance and Accounting, 5, 101-107.

[5] Salman, A.Y., Folajin, O. and Oriowo, A.O. (2017) Working Capital Management and Profitability: A Study of Selected listed manufacturing Companies in Nigerian Stock Exchange. International Journal of Academic Research in Business and Social Sciences, 4, 287-295. https://doi.org/10.6007/IJARBSS/v4-i8/1097

[6] Ikpefan, O.A. and Enahoro, J.A. (2007) Interface of Leverage and Earnings: An Investigation into the Nigerian Manufacturing Sector. The Nigerian Accountant, 40.

[7] Ehiremmen, O.S. (2017) Impact of Working Capital on the Profitability of Manufacturing Firms in Nigeria. Research Journal of Accounting, 5, 2-9.

[8] Izadinia, N. and Taki, A. (2010) Examination the Effects of Working Capital Management on Capability of Profitability for Listed Companies on Tehran Stock Exchange. Journal of Financial Accounting Research, 5, 120-139.

[9] Quayyum. S. (2011) Effects of Working Capital Management and Liquidity: Evidence from the Cement Industry of Bangladesh. Journal of Business and Technology (Dhaka), 6, 37-47. https://doi.org/10.3329/jbt.v6i1.9993

[10] Lazaridis, I. and Tryfonidis, D. (2006) Relationship between Working Capital Management and Profitability of Listed Companies in the Athens Stock Exchange. Journal of Financial Management and Analysis, 19, 26-38.

[11] Gul, S., Faiza, I. and Khalid, Z. (2011) Factors Affecting Bank Profitability in Pakistan. The Romanian Economic Journal, 2, 6-9.

[12] Dong, H.P. and Su, J. (2010) The Relationship between Working Capital Management and Profitability: A Vietnam Case. International Research Journal of Finance 
and Economics, 49, 62-70.

[13] Hampton, J.J. (2007) Financial Decision Making, Concepts, Problems and Cases. 4th Edition, Prentice Hall of India Private Limited, New Delhi.

[14] Pandey, I.M. (2005) Financial Management. 9th Edition, Vikas Publishing House PVT Ltd., New Delhi.

[15] Egbide, B. (2009) Working Capital Management and Profitability of Listed Companies in Nigeria. Nigeria Research Journal of Accountancy, 1, 44-57.

[16] Seyed, M.A. and Esmail, D. (2013) Studying the Relationship between Working Capital Management and Profitability of Listed Companies in Tehran Stock Exchange. Business Management Dynamics, 2, 1-8.

[17] Murthy, Y. and Sree, R. (2003) A Study on Financial Ratios of Major Commercial Banks. College of Banking \& Financial Studies, Research Studies.

https://www.researchgate.net/publication/228200738

[18] Khrawish, H.A. (2011) Determinants of Commercial Banks Performance: Evidence from Jordan. International Research Journal of Finance and Economics, 5, 19-45.

[19] Karaduman, H.A., Akbas, H.E., Ozsozgun, A. and Salih, D. (2010) Effects of Working Capital Management on Profitability: The Case for Selected Companies in The Istanbul Stock Exchange (2005-2008). International Journal of Economics and Finance Studies, 2, 47-54.

[20] Falope, O.I. and Ajilore, O.T. (2009) Working Capital Management and Corporate Profitability: Evidence from Panel Data Analysis of Selected Quoted Companies in Nigeria. Research Journal of Business Management, 3, 73-84. https://doi.org/10.3923/rjbm.2009.73.84

[21] Akoto, R.K., Vitor, D.A. and Angmor, P.L. (2013) Working Capital Management and Profitability: Evidence from Ghanaian listed Manufacturing Firms. Journal of Economics and International Finance, 5, 373-379. https://doi.org/10.5897/JEIF2013.0539

[22] Eljelly, A. (2004). Liquidity-Profitability Tradeoff: An Empirical Investigation in an Emerging Market. International Journal of Computational Methods, 14, 48-61. https://doi.org/10.1108/10569210480000179

[23] Smith, K. (1980) Profitability versus Liquidity Tradeoffs in Working Capital Management, Readings on the Movement of Working Capital. West Publishing Company, New York, St. Paul.

[24] Richards, V.D. and Laughlin, E.J. (1980) A Cash Conversion Cycle Approach to Liquidity Analysis. Financial Management, 9, 32-38. https://doi.org/10.2307/3665310

[25] Padachi, K. (2006) Trends in Working Capital Management and Its Impact on Firm's Performance: An Analysis of Mauritian Small Manufacturing Firms. International Review Business Research Papers, 2, 45-56.

[26] Egbide, B.C. and Enyi, P.E. (2008) Working Capital Management and Profitability; A Study of 25 Listed Companies in the Nigerian Stock Exchange. Master's Dissertation, Covenant University, Ota, Ogun State.

[27] Vijayakumar, A. (2011) Cash Conversion Cycle and Corporate Profitability-An Empirical Enquiry in Indian Automobile Firms. International Journal of Research in Commerce, IT \& Management, 1, 84-91.

[28] Raheman, A., Afza, T. and Quayyum, A. (2010) Working Capital Management and Corporate Performance of Manufacturing Sector in Pakistan. International Research Journal of Finance and Economics, 1, 152-163. 
[29] Akinlo, O.O. (2011) The Effect of Working Capital on Profitability of Firms in Nigeria: Evidence from General Method of Moments (GMM). Asian Journal of Business and Management Sciences, 1, 130-135.

[30] Jinadu, M.K. (1987) Occupational Health and Safety in a Newly Industrializing Country. The Journal of the Royal Society of Health, 107, 8-10. https://doi.org/10.1177/146642408710700104

[31] Rehman, A. (2006) Working Capital Management and Profitability: Case of Pakistani Firms. Dissertation, COMSATS Institute of Information Technology Islamabad, Pakistan.

[32] Charitou, M.S., Elfan, M. and Lois, P. (2010) The Effect of Working Capital Management on Firms Profitability: Empirical Evidence from an Emerging Market. Journal of Business and Economic Research, 8, 63-68.

https://doi.org/10.19030/jber.v8i12.782 